\section{Sjogren's syndrome with pulmonary nodular light chain deposition disease; response to mycophenolate mofetile}

\author{
Vijay Aluri," Nabih I Abdou² \\ 'University of Missouri Kansas City \\ School of Medicine, Kansas City, MO, \\ USA \\ ${ }^{2}$ Center for Rheumatic Diseases, Allergy \\ and Immunology, Kansas City, MO, USA
}

\begin{abstract}
Light chain deposition disease associated with primary Sjogren's syndrome has been rarely reported in the medical literature. We report a 65-year old Caucasian woman with Sjogren's syndrome (SS) for twenty eight years associated with nodular pulmonary light chain deposition disease. This case is unique in the improvement of clinical symptoms and pulmonary function tests following treatment with mycophenolate mofetil (MMF). Primary SS is an automimmune exocrinopathy which is characterized by keratoconjunctivitis sicca and xerostomia. SS is known to be associated with B cell hyperactivity, polyclonal gammopathy and low grade marginal zone B cell lymphoma. Light chain deposition disease is a non-amyloid monoclonal immunoglobulin disorder that is caused by a clonal plasma cell proliferative disorder. Tissue deposits in light chain deposition disease are granular not fibrillar, and do not stain with Congo Red. The coexistence of SS and light chain depositon disease is unusual.
\end{abstract}

\section{Case Report}

W. is a 65-year old non-smoking Caucasian female who had sicca symptoms without sclerodactylia for twenty eight years. On laboratory testing, she had positive ANA, rheumatoid factor, elevated erythrocyte sedimentation rate, elevated Anti Ro/SSA, normal serum creatinine and normal liver function tests and multiple pulmonary nodules on chest X ray since 1995 . Patient developed progressive dyspnea and became oxygen dependent since 2005. A CT scan of the chest done prior to mycophenolate mofetil (MMF) therapy showed extensive bullous emphysematous disease and multiple calcified nodules in both lung fields. There was no evidence for pulmonary embolism, axillary or mediastinal adenopathey.

Patient had an abdominal fat pad biopsy and a CT guided lung biopsy in 2006. Congo Red stain was negative for amyloid in the fat pad biopsy as well as in the pulmonary fine needle aspirate. Patient had an open lung biopsy in February 2008 which showed- nodular calcifications, no granulomas, and increased perivascular collagen around medium to large pulmonary arteries. Cultures for fungal infections, bacterial, or tuberculosis were negative. Congo Red stain was negative for amyloid. However, immunohistochemical staining was positive for both kappa and lambda light chains. Patient's serum protein electrophoresis (SPEP) was positive for a monoclonal protein IgG lambda of $0.7 \mathrm{~g} / \mathrm{dL}$. Further work up for gammopathy revealed elevated plasma free kappa and lambda light chains at $31.8 \mathrm{mg} / \mathrm{L}$ (normal range $3.3-19.4 \mathrm{mg} / \mathrm{L}$. ) and $38.30 \mathrm{mg} / \mathrm{L}$ (normal range $5.7-26.3 \mathrm{mg} / \mathrm{L}$.) respectively in August, 2008. Patient declined a bone marrow biopsy and a lip biopsy.

Prior to MMF therapy, our patient had been on oral cyclophosphamide and oral prednisone since 1995. Hydroxychloroquine $400 \mathrm{mg}$ per day was added with oral steroids in 2001, and then she was switched to azathioprine and steroids in 2002. This therapy proved ineffective in improving pulmonary functions and did not decrease the size or number of pulmonary nodules seen on chest x-ray. Patient was then started on MMF 1000 mg po bid in April 2008, and was continued on Hydroxychloroquine $200 \mathrm{mg}$ po bid and prednisone $20 \mathrm{mg}$ po daily. MMF therapy resulted in improvement in her clinical symptoms (dyspnea) and her pulmonary function tests (Table 1) but not in her pulmonary diffusion capacity or her chest $\mathrm{X}$ ray (Figure 1). The residual nodular opacities probably represented calcifications.

\section{Discussion}

Although Sjogren's syndrome (SS) has been reported to have been associated with localized amyloidosis ${ }^{1-4}$ only isolated case reports of SS have been described in association with systemic primary amyloidosis. ${ }^{5}$ One case of multiple myeloma and primary amyloidosis mimick-

Table 1. Comparison of pulmonary function tests and chest $\mathrm{X}$ ray prior to and after initiation of mycophenolate mofetil.

\begin{tabular}{lll}
$\begin{array}{l}\text { Pulmonary function } \\
\text { tests }\end{array}$ & $\begin{array}{l}\text { Before starting } \\
\text { mycophenolate } \\
\text { mofetil }\end{array}$ & $\begin{array}{l}\text { After starting } \\
\text { mycophenolate } \\
\text { mofetil }\end{array}$ \\
Date & September 2007 & July 2008 \\
FEV1 & 1.37 liter & 1.50 liter \\
\hline FVC & 2.02 liters & 2.11 liters \\
FEV1/ FVC ratio & $67.8 \%$ & $71 \%$ \\
\hline Chest X ray findings & Nodular opacities & $\begin{array}{l}\text { Nodular opacities } \\
\text { opacities (unchanged) }\end{array}$
\end{tabular}

Correspondence: Nabih I. Abdou, Center for Rheumatic Diseases, Allergy and Immunology, 4330 Wornall Road, Ste 40, Kansas City, M0 64111. USA. E-mail: niabdou@centerforrheumatic.com

Key words: Sjogren's syndrome, autoimmune disease, light chain deposition disease.

Received for publication: 17 August 2009. Revision received: 13 0ctober 2010.

Accepted for publication: 6 December 2010.

Acknowledgements: we thank our patient for her co-operation. We thank Dr. Robert Belt of Kansas City Cancer Center for his input in defining the monoclonal protein. We thank Dr. Ann Romaker of Romaker and Associates for her assistance in the patient's care; and Cindy Greenwell, RN CCRC, at the Center for Rheumatic Disease, for her participation in the patient's care as well as the submission process of this case report.

This work is licensed under a Creative Commons Attribution 3.0 License (by-nc 3.0).

(C) Copyright V. Aluri and N.I. Abdou, 2011

Licensee PAGEPress, Italy

Rheumatology Reports 2011; 3:e1

doi:10.4081/rr.2011.e1

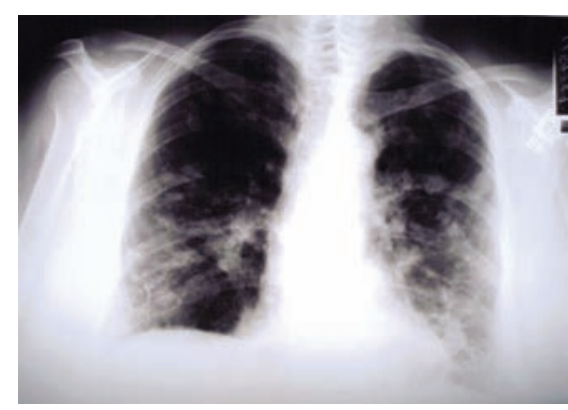

Figure 1. Chest X-ray showing no improvement after MMF therapy. 
ing SS has been reported. ${ }^{6}$ There are few reported cases of systemic light chain fragments that do not have the biochemical characteristics to form amyloid fibrils. ${ }^{6,7}$ Therefore the light chain deposition disease is labeled as a non-amyloid monoclonal immunoglobulin light chain.

We believe that MMF was efficacious in the treatment of our patient who had SS with pulmonary manifestations. MMF is a selective inhibitor of Inosine monophosphate (IMP) dehydrogenase which is an important enzyme in de novo purine synthesis that converts Inosine monophosphate to xanthine monophosphate. Inhibition of IMP dehydrogenase, expressed by results in decreased nucleotide synthesis by the de novo pathway. The antiproliferative effect of MMF mainly affects activated T- and B-lymphocytes because their proliferation is critically dependent on the novo purine syntesis. MMF preferentially binds to type II isoform of IMP dehydrogenase, expressed by activated lymphocytes. ${ }^{8}$ MMF however could lead to immunosuppression through other mechanisms, including apoptosis of activated T-lymphocytes, and inhibition of adhesion molecule expression and lymphocyte recruitment. ${ }^{9}$ Since both T and B cells have been suggested to have a pivotal role in the immunopathogensis of primary $\mathrm{SS},{ }^{10,11}$ MMF may be a promising drug in the management of SS and the lymphoproliferative disorders associated with this syndrome.
Our case demonstrated improvement of pulmonary function tests as well as her pulmonary complaints upon therapy with MMF. However our patient diffusion capacity to carbon monoxide (DLCO) did not change following MMF therapy. We do realize that further studies and randomized clinical trials in similar patients are warranted to establish the efficacy of MMF in the management of SS with light chain depositon disease. Recent reports have indicated however no improvement in survival of patients with amyloidsis associated with inflammatory rheumatic diseases. ${ }^{12}$

\section{References}

1. Pablos JL, Cogolludo V, Pinedo F, Carreira PE. Subcutaneous nodular amyloidosis in Sjögren's syndrome. Scand J Rheumatol 1993;22:250-1

2. Kobayashi H, Matsuoka,R, Kitamura S, et al. Sjögren's syndrome with multiple bullae and pulmonary nodular amyloidosis. Chest 1988;94:438-40.

3. Niepolski L, Grzegorzewska AE, Szymaś J. Nodular pulmonary amyloidosis and Sjögren's syndrome in a patient treated with intermittent hemodialysis. Hemodial Int 2007;11:406-10.

4. Katsikas GA, Maragou M, Rontogianni D, et al. Secondary cutaneous nodular AA amyloidosis in a patient with primary Sjögren syndrome and celiac disease. J Clin Rheumatol 2008;14:27-9.

5. Delèvaux I, André M, Amoura Z, et al. Concomitant diagnosis of primary Sjögren's syndrome and systemic AL amyloidosis. Ann Rheum Dis 2001;60:694-5.

6. Schlesinger I. Multiple myeloma and AL amyloidosis mimicking Sjögren's syndrome. South Med J 1993;86:568-9.

7. Kijner CH, Yousem SA. Systemic light chain deposition disease presenting as multiple pulmonary nodules. A case report and review of the literature. Am J Surg Pathol 1988;12:405-13.

8. McMurray RW, Harisdangkul V. Mycophenolate mofetil: selective T cell inhibition. Am J Med Sci 2002;323:194-6.

9. Allison AC, Eugui EM. Mycophenolate mofetil and its mechanisms of action. Immunopharmacology 2000;47:85-118.

10. Zumla A, Mathur M, Stewart J, et al. T cell receptor expression in Sjögren's syndrome. Ann Rheum Dis 1991;50:691-3.

11. Price EJ, Venables PJ. The etiopathogenesis of Sjögren's syndrome. Semin Arthritis Rheum 1995; 25:117-33.

12. Immonen K, Finne P, Hakala M, et al. No improvement of patients with amyloidosis associated with inflammatory rheumatic diseases. Data from the Finnish National Registry for Kidney Diseases. J Rheumatol 2008;35:1334-8. 